\title{
Evaluation of muscle tissue and liver glycogen of cattle submitted to transport over long distances and subjected to emergency slaughter
}

\author{
[Avaliação do tecido muscular e glicogênio hepático de bovinos transportados por longas distâncias e \\ submetidos ao abate de emergência]
}

\author{
L.V. Burns ${ }^{1}$, A.T. Ramos ${ }^{2}$, A.P.M. Veiga ${ }^{2}$, S.E. Moron ${ }^{1}$, F.M. Cordova ${ }^{1}$, F.R.C. Miotto ${ }^{1}$, \\ E.B. Viana ${ }^{3}$, F.C. Zimermann ${ }^{2}$, S. Minharro ${ }^{1}$, N.R. Stefanine ${ }^{4}$, L.F. Sousa ${ }^{1}$ \\ ${ }^{1}$ Universidade Federal do Tocantins - Araguaína, TO \\ ${ }^{2}$ Universidade Federal de Santa Catarina - Curitibanos, SC \\ ${ }^{3}$ Universidade Federal de Juiz de Fora - Juiz de Fora, MG \\ ${ }^{4}$ Faculdade Católica Dom Orione - Araguaína, TO
}

\author{
L.V. Burns \\ https://orcid.org/0000-0002-6776-0245 \\ A.T. Ramos
https://orcid.org/0000-0001-8744-5309 \\ F.M. Cordova \\ https://orcid.org/0000-0003-4735-4108 \\ .E. Moron \\ https://orcid.org/0000-0002-1359-6160 \\ A.P.M. Veiga \\ https://orcid.org/0000-0003-0236-2913 \\ F.C. Zimermann \\ https://orcid.org/0000-0002-6379-3656 \\ L.F. Sousa \\ https://orcid.org/0000-0002-6072-9237 \\ N.R. Stefanine \\ https://orcid org/0000-0001-8289-9520 \\ h.tps://orcid.org/0000-0001-5844-5326 \\ F.R.C. Miotto \\ https://orcid.org/0000-0002-6989-2698 \\ .B. Vian \\ ttps://orcid.org/0000-0003-4793-3994
}

\begin{abstract}
The study evaluated the effect of transportation over long distances on cattle muscle tissue of submitted to emergency slaughter in slaughterhouses in northern Tocantins, Brazil. The evaluations consisted in $\mathrm{pH}$, muscle and liver glycogen, muscle histopathology and creatine kinase (CK), alanine aminotransferase (ALT) and aspartate aminotransferase (AST) activity. Animals were placed into two groups: Experimental Group (EG), consisting of 19 bovines intended for immediate emergency slaughter, and Control Group (CG), composed of 24 bovines slaughtered in accordance with the normal flow. CK and ALT levels were high in EG. AST did not differ between groups. EG showed higher muscle pH and mean of degenerate fibers, mainly on the intercostal. However, muscle and liver glycogen did not differ between groups. In conclusion, cattle transported over long distances and subjected to immediate emergency slaughter showed markedly stress condition, with changes in biochemical parameters in the muscle tissue, determined by cellular degeneration.
\end{abstract}

Keywords: bovine, muscle degeneration, muscle glycogen, stress, $\mathrm{pH}$

\section{RESUMO}

O presente trabalho objetivou avaliar o efeito do transporte em longas distâncias sobre o tecido muscular de bovinos encaminhados ao abate de emergência. Foram avaliados $\mathrm{pH}$, glicogênio muscular e hepático, análise histopatológica muscular, creatina quinase (CK), alanina aminotransferase (ALT) e aspartato aminotransferase (AST). Os animais foram alocados em dois grupos: grupo experimental $(G E)$, constituído por 19 bovinos destinados ao abate de emergência, e grupo controle (GC), composto por 24 bovinos abatidos de acordo com o fluxo normal do frigorífico. A CK e a ALT estavam aumentadas no GE. O AST não diferiu entre os grupos. $O$ GE apresentou maior percentual de fibras degeneradas, $e$ o músculo intercostal teve maior quantidade de degenerações. $O$ pH muscular foi superior no GE. $O$ glicogênio muscular e o hepático não diferiram entre os grupos. Concluiu-se que bovinos encaminhados ao abate de emergência sofrem estresse severo pelo transporte por longas distâncias, com alterações bioquímicas no tecido muscular determinada pela degeneração celular.

Palavras-chave: bovino, degeneração muscular, glicogênio muscular, estresse, $p H$

\section{INTRODUCTION}

Transport is considered the main cause of stress, damaging bovine's health and welfare (Bulitta $e t$ al., 2015). Loading, unloading, confinement, vibrations, social regrouping, unknown

Recebido em 9 de agosto de 2017

Aceito em 6 de outubro de 2018

E-mail: leoburns@uft.edu.br environments, deprivation of water and food (Miranda-De La Lama et al., 2014), and traveling time or long distance are important potential stressors (Bulitta et al., 2015). Under these conditions, animals can manifest fear, dehydration, hunger, increase in physical activity, fatigue and muscle injuries (Ferguson and Warner, 2008). 
This can influence the cattle welfare, resulting in economic losses by reducing the carcass weight, increased bruising and raising the muscle $\mathrm{pH}$, producing meat with dark cuts (Gallo et al., 2003). Stress or increase in physical activity on the pre-slaughter period may cause depletion of muscle glycogen stores, with slight decrease in final $\mathrm{pH}$ ( $\mathrm{pH}$ close to neutrality), increasing the risk of DFD (dark, firm and dry) meat production (Terlouw et al., 2008).

The most used serum enzyme in the determination of diverse neuromuscular diseases in domestic animals is creatine kinase $(\mathrm{CK})$ and its expressed in skeletal muscle (Cardinet, 1997). As well as CK, blood activities of other enzymes such as alanine aminotransferase (ALT) and aspartate aminotransferase (AST) also are elevated after muscle injuries (Valentine and McGavin, 2013).

In those prolonged transport conditions, some animals can reach the slaughterhouse sick, dying, recumbent, fractured, bruised, hypo or hyperthermic (Brasil, 2017). In such conditions, the Brazilian Federal Inspection system determines that these animals are sent for emergency slaughter, which is the immediate slaughter of the animals (Brasil, 2017). The reasons for such slaughter may be related to stressful situations, occurring more frequently in cows, and the main causes are injuries to the musculoskeletal system (Pisteková et al., 2004). Currently, the carcasses from emergency slaughter are intended for conditional use; however, the actual biochemical and morphological characteristics of meat are not known. Therefore, it is important to obtain more information about the carcasses conditions, allowing slaughterhouses to make a better decision about the best use of the meat, without compromising the quality of the product to the final consumer.

The aim of this study was to evaluate the effect of long distances transportation in bovines submitted to emergency slaughter, analyzing glycogen levels in liver and muscles, $\mathrm{pH}$ and morphological changes from different muscles, and biochemical profile (CK, AST and ALT serum activity).

\section{MATERIAL AND METHODS}

The experiment was conducted in slaughterhouses that are under Federal Inspection Service, located north on the State of Tocantins, from January to July 2013. All cattle sampled were transported to the slaughterhouse in three axle single units or five or more axle single trailer trucks, according to the maximum capacity (20 animals in single units and 30 in trailers). Later, the animals were classified into two groups: experimental group (EG) and control group (CG). EG consisted on 24 animals intended for immediate emergency slaughter, and were slaughtered soon after arriving in the slaughterhouse. These animals traveled approximately $695 \mathrm{~km}$ in 12 hours of transportation from farms located in the states of Mato Grosso (MT), Pará (PA) and Tocantins (TO). The CG consisted on 24 animals, including 19 cows and 05 oxen belonging to farms located near the slaughterhouse, traveling approximately $100 \mathrm{~km}$ in three hours of transportation. These animals were slaughtered in accordance with the slaughterhouse normal flow, following a 12-hour period of food and water fasting. It is important to emphasize that the carcass of $\mathrm{CG}$ and $\mathrm{EG}$ received electrical stimulation.

The animals from both groups were stunning before slaughter with airgun or captive bolt. Blood and tissues sampling in EG were carried out in different slaughterhouses, according to the occurrence of emergency slaughter cases. However, the collections in CG were made in a single slaughterhouse, randomly, on scheduled days. The study was approved by the local Ethical Committee for Animal Research (CEUAUFT; Process 23101.003943/2012-01).

A volume of $10 \mathrm{~mL}$ of blood was obtained individually from 19 cattle in the EG and from 24 cattle in the CG during exsanguination, using tubes without anticoagulant and clot activator, to obtain serum intended for biochemical analysis. Samples were identified and refrigerated tubes sent to the Morphology and Biochemistry Laboratory and Clinical Veterinary Pathology Laboratory at the Universidade Federal do Tocantins for processing on the same day. 
The laboratory tests were performed with the serum obtained by sample centrifugation (centrifuge $80-2 \mathrm{~B}$, Centribio, PRC) at 3,605g for 6 minutes to determine serum alanine aminotransferase (ALT) and aspartate aminotransferase (AST) with spectrophotometer (Asys UVM340, Biochrom Ltd., Cambridge, UK). Serum activity of creatine kinase (CK) was determined in semiautomatic spectrophotometer (BIOPLUS S ${ }^{\circledR}$, Bioplus, SP, Brazil). Commercial kits (Labtest Diagnóstica S.A., MG, Brazil) were used for all analysis.

For histopatological analysis Single fragments from muscles intercostal, abdominal internal oblique, semitendinosus (due to their anatomical locations susceptible to trauma during the preslaughter management) and psoas major (because it is a muscle that provides noble cut, the tenderloin) were collected. On these samples, morphometric analysis was performed on the 24 cattle belonging to EG and on the 24 cattle in CG, totaling 192 tests. Samples were collected directly into half-carcasses, selected randomly, corresponding to each animal at the end of the slaughter line. Then, the samples were sent to the Veterinary Pathology Laboratory at the Universidade Federal do Tocantins, placed in flasks containing $10 \%$ formalin, fixed for 72 hours, routinely processed and stained with hematoxylin and eosin (HE). Analysis was performed under an optical microscope $\left(\mathrm{DM} 500^{\circledR}\right.$, Leica Microsystems, Heerbrugg, Switzerland).

Muscle morphometric evaluation was made in cross sections in each slide, classifying them into normal and degenerated. We considered degenerate fibers with loss of polyhedral pattern and hyaline appearance. The images were projected directly on the monitor by a computer program (LAS $\mathrm{EZ}^{\circledR}$, Leica Microsystems, Heerbrugg, Switzerland) at 40x objective. The fibers quantification was made in different fields in histological sections, starting at the tissue lower left field, following diagonally to the total count of 300 muscle fibers, modified from McCormack et al. (2008).

For muscle and liver glycogen analysis, fortyeight samples $(\mathrm{CG}=24$ and $\mathrm{EG}=24)$ of liver with $4 \times 4 \mathrm{~cm}$ were collected after evisceration on the slaughter line. Also, a fragment of $4 \mathrm{x} 4 \mathrm{~cm}$ of muscles (psoas major, semitendinosus, intercostal and abdominal internal oblique), totaling 192 samples $(\mathrm{CG}=96$ and $\mathrm{EG}=96)$ were collected at half-hot carcasses corresponding to each animal at the end of slaughter (normal or immediate emergency). The samples were packed in plastic bags and refrigerated at the time of collection, subsequently frozen at $-20^{\circ} \mathrm{C}$ and sent to the Morphology and Biochemistry Laboratory for glycogen levels determination in a spectrophotometer (Asys UVM340, Biochrom Ltd., Cambridge, UK). Among the samples of frozen tissue, fragments of $0.1 \mathrm{~g}$ of liver, and $0.2 \mathrm{~g}$ of each muscle were removed with a scalpel and placed in flasks for analysis of glycogen concentrations, according to the methodology described by Dubois et al. (1956).

For the evaluation of ultimate $\mathrm{pH}\left(\mathrm{pH}_{\mathrm{u}}\right)$, frozen samples of psoas major, semitendinosus, intercostal and abdominal internal oblique obtained of half-hot carcasses $(\mathrm{CG}=96$ and $\mathrm{EG}=$ $96)$, were stored in the refrigerator $\left(2\right.$ to $8^{\circ} \mathrm{C}$ ) for 36 hours to promote slow defrosting. After this procedure, $\mathrm{pH}_{\mathrm{u}}$ was measured for each muscle sample using a pH meter (Testo $205^{\circledR}$, Testo, Lenzkirch, DE).

For statistical analysis, biochemistry data (CK, AST and ALT) were submitted to KolmogorovSmirnov normality test and homogeneity of variance. Normal variables were subjected to analysis of variance in a completely randomized design with two treatments CG and EG, and the treatment means compared by the Student t-test at $5 \%$ error probability. Glycogen concentrations, $\mathrm{pH}$, and muscle fiber degeneration percentage were arranged and analyzed in completely randomized design in split plots. The plots were the treatments (EG and CG) and the subplots were the different collected muscles. A Pearson correlation test among CK, ALT and AST enzymes and the muscle fiber degeneration percentages and a Spearman correlation test in the muscle groups between $\mathrm{pH}$ and the concentration of muscle glycogen were also performed.

\section{RESULTS}

There were significant differences in serum CK between groups $(\mathrm{P}=0.0001)$, with $\mathrm{EG}$ values higher than CG (Table 1). There was also significant difference between the groups at serum $\operatorname{ALT}(\mathrm{P}=0.0041)$, and the average was 
higher in the EG compared to CG. In the evaluation of AST, there was no difference between groups $(\mathrm{P}=0.7102$; Table 1$)$. The significant correlation of ALT was verified with the enzymes AST $(r=0.4630, P=0.002)$ and $C K$ $(r=0.3017, P=0.052)$ and with the percentage of degeneration in the intercostal muscle $(\mathrm{r}=$ 0.3637; $\mathrm{P}=0.017)$, psoas major $(\mathrm{r}=0.3080, \mathrm{P}=$ 0.047 ) and semitendinosus $(\mathrm{r}=0.3883, \mathrm{P}=$ 0.011). As for $C K$, it showed a significant correlation with ALT $(r=0.3017, \mathrm{P}=0.052)$ and degeneration percentage with the intercostal muscle $(\mathrm{r}=0.4876, \mathrm{P}=0.001)$, internal oblique abdominal $(\mathrm{r}=0.5108 ; \mathrm{P}=0.0005)$, psoas major $(\mathrm{r}=0.6179, \mathrm{P}=0.0001)$ and semitendinosus $(\mathrm{r}=$ $0.4301, \mathrm{P}=0.004)$.
During the animals' inspection for emergency slaughter (Figure 1A), extensive bleeding areas of subcutaneous and muscles were observed (Figure 1B).

Histopathologic evaluation of animals' muscle tissue revealed significant difference $(\mathrm{P}=0.0001)$ in percentage of degenerate fibers between EG and CG, with the highest average in EG (Figure 2).

Comparing the muscles individually (EG intercostal x CG intercostal, EG psoas major $\mathrm{x}$ CG psoas major, EG abdominal internal oblique $\mathrm{x}$ CG abdominal internal oblique, EG semitendinous x CG semitendinous) we observed high amount of degenerated fibers in all EG muscles $(\mathrm{P}=0.0001$, Table 2$)$.

Table 1. Effect of transportation in serum activity of creatine kinase (CK), aspartate aminotransferase (AST) and alanine aminotransferase (ALT) of cattle transported over long distances and sent to immediate emergency slaughter (EG) and slaughter line cattle transported over short distances (CG)

\begin{tabular}{lcccc}
\multicolumn{1}{c}{ Variable } & GC & GE & Standard error of the mean & P* \\
\hline CK (UI L-1) & $1170 \mathrm{a}$ & $18340 \mathrm{~b}$ & 120.17 & 0.0001 \\
AST (UI L-1) & 46.914 & 47.863 & 2.86 & 0.7102 \\
ALT (UI L-1) & $43.33 \mathrm{a}$ & $52.08 \mathrm{~b}$ & 3.05 & 0.0041 \\
\hline
\end{tabular}

Means followed by different lowercase letters $(\mathrm{a}, \mathrm{b})$ on the row are statistically different at $5 \%$ probability by the Student $t$-test.

* Probability of error type 1.
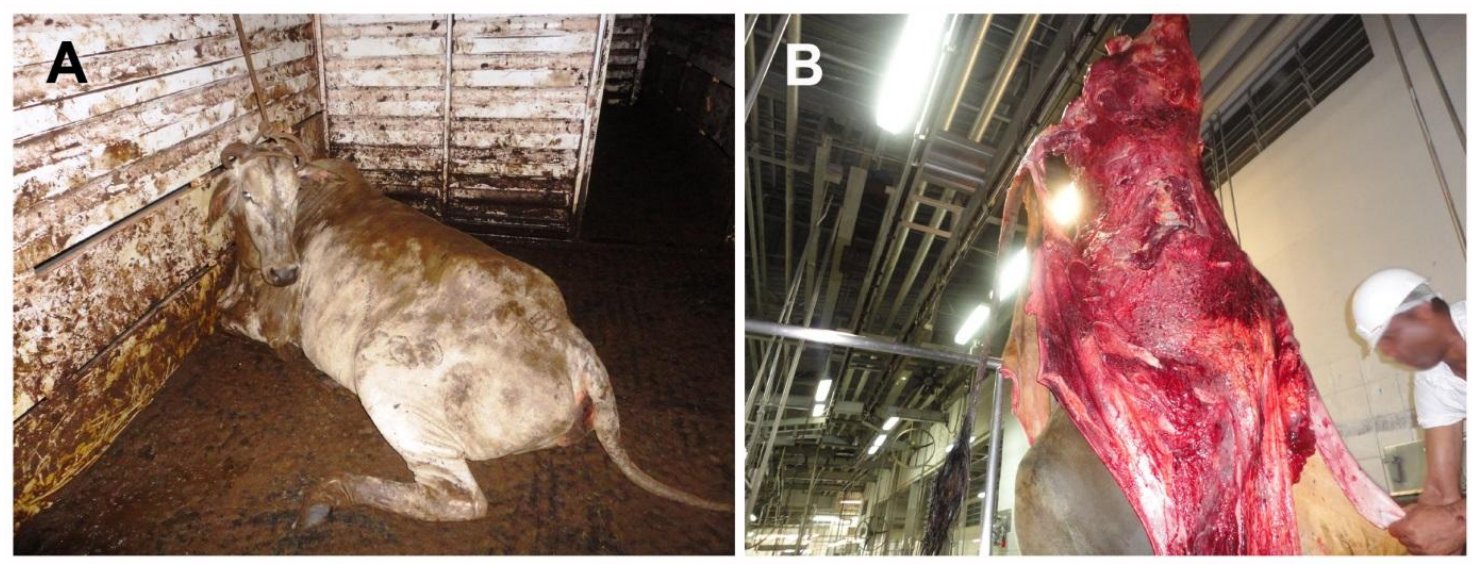

Figure 1. Cattle emergency slaughter transported to the slaughterhouse. (A) Bovine recumbent inside the truck when arriving at the slaughterhouse, sent to the immediate emergency slaughter. (B) Carcass with large areas of subcutaneous and muscle bleeding, observed during the slaughter procedure. 


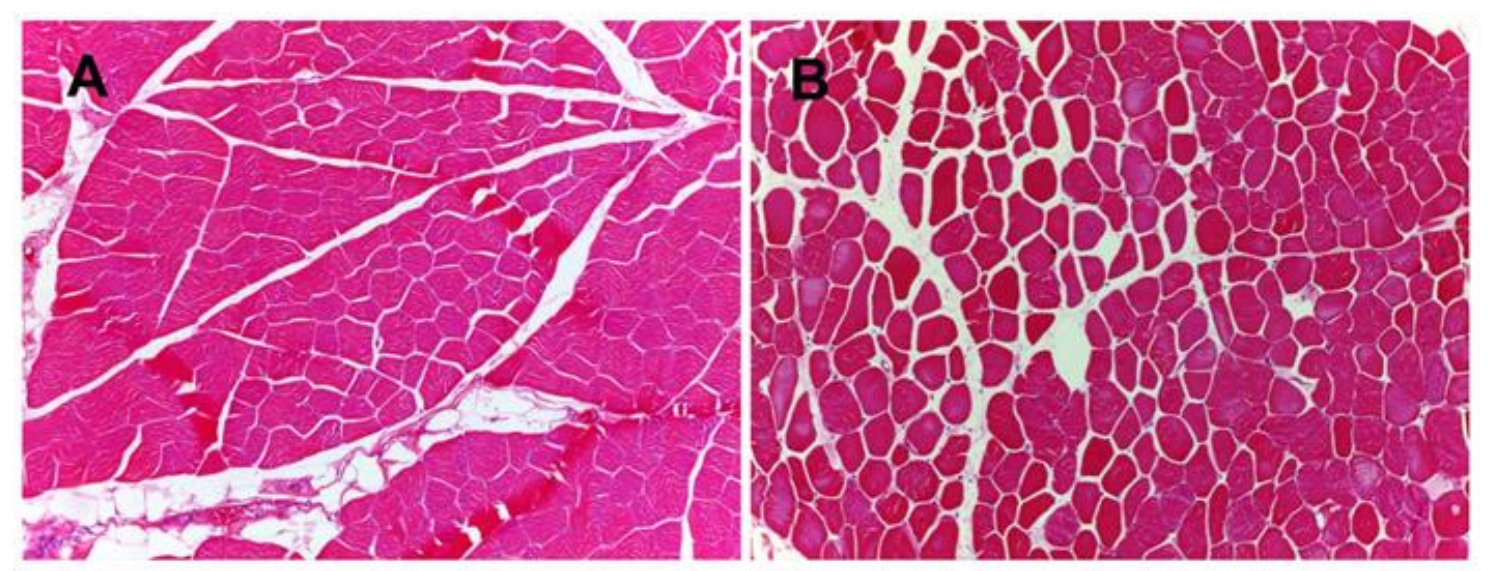

Figure 2. Muscle histopathological evaluation of bovines from routine slaughter line (CG) or slaughtered in emergency (EG). (A) CG bovine intercostal muscle with normal tissue appearance. HE, 10X objective. (B) EG bovine intercostal muscle with hyalinized fibers and loss of polyhedral pattern. HE, 10X objective.

Table 2. Degeneration, $\mathrm{pH}$ and muscle glycogen values of cattle transported over long distances and sent to immediate emergency slaughter (EG) and slaughter line cattle transported over short distances (CG)

\begin{tabular}{|c|c|c|c|c|c|c|}
\hline Variables & Groups & Intercostal & $\begin{array}{l}\text { Psoas } \\
\text { Major }\end{array}$ & $\begin{array}{c}\text { Internal } \\
\text { Abdominal } \\
\text { Oblique }\end{array}$ & Semitendinous & Mean \\
\hline \multirow{3}{*}{$\begin{array}{l}\text { Degenerate } \\
\text { fibers }(\%)\end{array}$} & EG & $34.76 \mathrm{Aa}$ & $30.66 \mathrm{Aa}$ & $15.08 \mathrm{Ab}$ & $13.45 \mathrm{Ab}$ & 23.48 \\
\hline & $\mathrm{CG}$ & $7.32 \mathrm{~B}$ & $3.94 \mathrm{~B}$ & $3.58 \mathrm{~B}$ & $3.68 \mathrm{~B}$ & 4.63 \\
\hline & MPM* & 21.04 & 17.30 & 9.33 & 8.56 & 14.05 \\
\hline \multirow{3}{*}{$\mathrm{pH}$} & EG & 6.40 & 6.38 & 6.43 & 6.34 & $6.39 \mathrm{~A}$ \\
\hline & $\mathrm{CG}$ & 5.82 & 5.58 & 5.70 & 5.57 & $5.67 \mathrm{~B}$ \\
\hline & MPM* & 6.11 & 5.98 & 6.06 & 5.95 & 6.03 \\
\hline \multirow{3}{*}{$\begin{array}{l}\text { Muscle } \\
\text { glycogen } \\
(\mu \mathrm{mol} g-1)\end{array}$} & $\mathrm{EG}$ & 21.50 & 20.47 & 19.22 & 23.69 & 21.22 \\
\hline & $\mathrm{CG}$ & 26.04 & 23.24 & 21.91 & 34.85 & 26.51 \\
\hline & MPM* & 23.77 & 21.85 & 20.56 & 29.27 & 23.86 \\
\hline
\end{tabular}

Means followed by different lowercase letters in rows and different uppercase letters in columns differ at 5\% probability of error type 1 by Student's $t$-test.

* Mean per muscle.

The percentage of degenerated fibers between the EG muscles, intercostal and psoas major were statistically different from the other EG muscle groups $(\mathrm{P}=0.0001$; Table 2). The $\mathrm{pH}$ evaluation did not show interaction between different muscles groups in control and experimental groups $(\mathrm{P}=0.5374)$. Nevertheless, a lower $\mathrm{pH}$ in the $\mathrm{CG}(\mathrm{P}=0.0001)$ was evidenced (Table 2). There was a significant correlation between the semitendinosus muscle $\mathrm{pH}$ with the psoas major $\mathrm{pH}(\mathrm{r}=0.8920, \mathrm{P}=0.0005)$ and the internal oblique abdominal $\mathrm{pH}(\mathrm{r}=0.9615, \mathrm{P}=$ $0.0001)$.

There was no significant difference in muscle glycogen levels $(\mathrm{P}=0.9248)$ between the EG and CG (Table 2). No significant difference between $\mathrm{CG}$ muscles $(\mathrm{P}=$ 0.9388) was found. Additionally, no difference in liver glycogen $(\mathrm{P}=$ 0.1199 ) was observed (Table 3 ). 
Table 3. Effect of transport on liver glycogen concentrations of cattle transported over long distances and sent to immediate emergency slaughter (EG) and slaughter line cattle transported over short distances (CG)

\begin{tabular}{|c|c|c|c|}
\hline \multirow{2}{*}{ Variable } & \multicolumn{2}{|c|}{ Groups } & \multirow{2}{*}{ Mean } \\
\hline & EG & $\mathrm{CG}$ & \\
\hline Glycogen ( $\mu$ mol g-1) & 54.77 & 62.60 & 57.92 \\
\hline
\end{tabular}

Probability of error type 1 by the F-test.

\section{DISCUSSION}

The CK, AST and ALT increased activities in the blood result from tissue damage, low perfusion in muscle tissue, reduced heat dissipation, hypoxia and fatigue (Lopez et al., 2006). The significant increase in serum AST activity can be related to more severe muscular lesions, considering the presence of this enzyme not only in the cytoplasm, as observed in the CK and ALT, but also in mitochondria (Stockham and Scott, 2011). The correlations of CK, ALT and AST serum activities among each other and with muscle degeneration were significant, confirming the severity of muscle injuries. Bernardini et al. (2012) describe an increase in $\mathrm{CK}$ and AST activities in bovines transported by long distances, however CK does not always rise due to the duration of trip, being very sensitive to shocks and bruises that occur during transport (Fisher et al., 2009). Ishiwata et al. (2008) report elevation of ALT in cattle transported over long distances, corroborating the results obtained in our study.

CK and ALT serum activity was higher in EG compared to $\mathrm{CG}$, however, in both groups they were far above the reference values for bovines, in which the CK ranges from 4.8 to $12.1 \mathrm{UI}$ L-1 and the ALT from 11 to 40UI L-1 (Kaneko et al., 2008). This suggests that long transportation associated with severe muscle injury and degeneration of myofibers were extremely important factors for increased activity of enzymes in EG. In addition, despite the CG animals having traveled short distances, transportation associated with the waiting time before slaughter was sufficient to increase CK, ALT and AST serum activities compared to the reference values, characterizing compromised cellular integrity of the musculoskeletal system, albeit lower than the ones in EG.
Unfavorable transportation conditions and long transportation periods are situations that may increase the extent of bruising (Andrade et al., 2008), since weakened cows remain recumbent for longer, allowing the emergence of muscle trauma by increased risk of hypoxia and bruising (Hirvonen et al., 1997). The most common injuries during transportation occur mainly in the thoracic and abdominal region (Minka and Ayo, 2009), and cows, in relation to calf and bulls, are the most affected category (Romero et al., 2013), corroborating the locations of bruising and the category observed in this research.

Degenerative myopathies may occur due to trauma, ischemia, stress, nutritional and toxic disorders (Valentine and McGavin, 2013). In the EG, during the skinning, extensive subcutaneous and muscle bleeding were observed mainly in the lateral region, due to bruises caused by stepping during transportation. On arrival at the slaughterhouse, it was observed that all animals sent to emergency slaughter were in sternal or lateral (left or right) recumbency. Prolonged recumbency possibly contributed to the occurrence of muscle fibers degeneration, since it may cause ischemia by compressing blood vessels (Valentine and McGavin, 2013).

Animals in EG suffered greater effects of stress due to the longer distance and the extended journey. They also have suffered quite severe bruising during transportation compared to the ones in CG. Thus, in EG muscles that had higher percentages of degeneration were the intercostal and psoas major. Degenerations observed in the intercostal muscle may have occurred due to stepping, resulting in severe bruising and bleeding, or ischemia due to decubitus. The psoas major, a dynamic muscle with high energy requirement, used by cattle for locomotion or to remain standing (Moreno-Sánchez et al., 2008), 
may have suffered degeneration due to hypoxia or tissue anoxia as a result of hemorrhage.

Muscle glycogen levels and the final $\mathrm{pH}$ of the muscle are often used as indicators of fatigue or stress in animals (Minka and Ayo, 2009). The muscle glycogen concentrations vary according to species, nutritional status, type of muscle fiber, stress in the moments before slaughter (Hargreaves et al., 2004), distance and travel time, and time spent in the waiting corrals (Gallo, 2003). In the present study, the average glycogen muscle in EG was $21.22 \mu \mathrm{mol} \mathrm{g}-1$ and $26.51 \mu \mathrm{mol} \mathrm{g}-1$ in $\mathrm{CG}$, both lower than values considered normal, which was $60-120 \mu \mathrm{mol} g-1$ (Ferguson et al., 2001). Consumption and reduction of the stored glycogen may have occurred due to food restriction and action of catecholamines release during the stress of transportation, causing depletion of glycogen and consequently muscle acidification (Ferguson et al., 2001). Another important factor that can change the glycogen concentrations is the electrical stimulation of the carcass, which induces muscle contraction and acceleration of glycolysis and $\mathrm{pH}$ decline (rigor mortis), increasing the tenderness (Strydom and Frylinck, 2014). The result of the $\mathrm{EG} \mathrm{pH}_{\mathrm{u}}$ was 6.39 , higher than the $\mathrm{pH}$ that indicates the beginning of rigor mortis, which is approximately 5.9, and the rigor establishment, when the $\mathrm{pH}$ reaches a value near 5.5. This process is extremely important to maximize meat quality characteristics such as tenderness, juiciness, color and flavor (Terlouw et al., 2008). In the $\mathrm{CG}$, the $5.67 \mathrm{pH}_{\mathrm{u}}$ level was found as an indicative that the rigor process was established. The speed of $\mathrm{pH}$ reduction varies considerably between species, occurring slowly in cattle due to the reduced rate of glycolysis. Also, for cattle at the post-mortem the level of ATP is maintained initially by phosphocreatine (phosphocreatine + ADP $\leftrightarrow$ creatine + ATP) and, only after its muscle depletion is that glycogen will become the main source of cell energy. The initial $\mathrm{pH}$, which is around 7.0, drops to 6.8 to 6.4 after 5 hours and to 5.9 to 5.5 only after 24 hours (Roça, , 2001).

The $\mathrm{pH}_{\mathrm{u}}$ limit for the rating DFD meat is greater than 6.0, however some authors consider DFD to be meat with pH from 5.8 (England et al., 2016). Studies in Colombia reported that there was a positive correlation with the presence of bruises and hematomas in $37 \%$ of animals with $\mathrm{pH}$ higher than 5.8 (Romero et al., 2013). During the emergency slaughter it was found that the carcasses of EG cattle had extensive bruising and subcutaneous and muscle hematomas, mainly caused by stepping (trauma) occurred in transport. Nevertheless, these lesions were not observed in the carcasses of CG cattle. Considering these facts, suggest that the intense stress and presence of hematomas may have influenced the higher $\mathrm{pH}_{\mathrm{u}}$ in the EG animals.

As described previously, several factors affect the concentrations of glycogen and muscle $\mathrm{pH}$ values. Also, in the early post-mortem period, ATP used by the muscles originated from phosphocreatine metabolism, and the reserves of glycogen are degraded only after its exhaustion, which may have influenced the higher values of muscle $\mathrm{pH}_{\mathrm{u}}$ in EG. The animals of the CG showed $\mathrm{pH}_{\mathrm{u}}$ lower than the ones in the EG, possibly because they were not subjected to severe stress and remained in the waiting corrals under food deprivation for 12 hours for recovery from physical and psychological transport exhaustion.

The results of liver glycogen, both in EG $(54.77 \mu \mathrm{mol} \mathrm{g}-1)$ and in CG $(62.60 \mu \mathrm{mol} \mathrm{g}-1)$, were lower than those found in studies on the effect of supplementation of dairy cows, ranging from 86.8 to $168.4 \mu \mathrm{mol}$ g-1 (Damgaard et al., 2013). This reinforces the effect of food restriction and stress of transportation on reduced concentrations of glycogen in the liver. According to Roça (2001), aspects related to carbohydrate metabolism in the liver and nutritional factors influence concentrations of liver glycogen. In the liver is the largest carbohydrate reserve that can be easily breakdown during fasting or physical exercise (Minka and Ayo, 2009). In this way, the initial response of animals during transport stress is due to the increase in release of catecholamines (adrenaline / noradrenaline) and glucocorticoids (cortisol) in blood that stimulate hepatic glycogenolysis, increasing plasma glucose (Knowles et al., 2014). Animals in EG were slaughtered immediately after arriving at the slaughterhouse, while CG animals, traveled for a shorter period (three hours), remained at rest (twelve hours) and fasting, before being slaughtered. In this case, both EG and CG presented liver glycogen storage lower than animals from other studies that have not been 
submitted to the imminent slaughter (Damgaard et al., 2013). However, liver glycogen consumption was accelerated in EG (even at less waiting time for slaughter) compared to $\mathrm{CG}$, which can be explained by different moments of slaughter between the EG (immediate slaughter) and CG (slaughter after twelve hours of rest). This suggests that transportation on long distances and the resulting consequences (bruises, haematomas) provide higher levels of stress, although there was no statistically significant difference between liver glycogen levels of EG and CG.

\section{CONCLUSIONS}

Cattle transported over long distances and forwarded to the immediate emergency slaughter present myofiber degeneration, increased CK and ALT serum activities and increased muscle $\mathrm{pH}$. The data provide relevant scientific contribution that reinforce the need for urgency in implementing welfare measures for the slaughter submitted animals, especially for those subjected to long-distance transport.

\section{ACKNOWLEDGEMENTS}

The authors are thankful to the Fundação de Amparo à Pesquisa do Tocantins (FAPT) for the fellowship conceded to Leonardo Vaz Burns.

\section{REFERENCES}

ANDRADE, E.N.; ROÇA, R.O.; SILVA, R.A.M.S. et al. Prevalência de lesões em carcaças de bovinos de corte abatidos no Pantanal Sul Mato-Grossense transportados por vias fluviais. Ciênc. Tecnol. Aliment., v.28, p.822-829, 2008.

BERNARDINI, D.; GERARDI, G.; PELI, A. et al. The effects of diferent environmental conditions on thermoregulation and clinical and hematological variables in long-distance roadtransported calves. J. Anim. Sci., v.90, p.11831191, 2012.

BRASIL. Ministério da Agricultura, Pecuária e Abastecimento. RIISPOA (Regulamento da Inspeção Industrial e Sanitária de Produtos de Origem Animal). Decreto 9.013, de 29 de março de 2017. DF:. 2017.
BULITTA, F.S.; ARADOM, S.; GEBRESENBET, G. Effect of transport time of up to 12 hours on welfare of cows and bulls. $J$. Serv. Sci. Manag., v.8, p.161-182, 2015.

CARDINET, G.H. Skeletal muscle function. In: KANEKO, J.J.; HARVEY, J.W.; BRUSS, M.L. (Eds). Clinical biochemistry of domestic animals. Londres: Academic Press, 1997. p.407-440.

DAMGAARD， B.M.; WEISBJERG， M.R.; LARSEN, T. Priming the cow for lactation by rapeseed supplementation in the dry period. $J$. Dairy Sci., v.96, p.3652-3661, 2013.

DUBOIS, M.; GILLES, K.A.; HAMILTON, J.K. et al. Colorimetric method for determination of sugars and related substances. Anal. Chem., v.28, p.350-356, 1956.

ENGLAND, E.M.; MATARNEH, S.K.; OLIVER, E.M. et al. Excess glycogen does not resolve high ultimate $\mathrm{pH}$ of oxidative muscle. Meat Sci., v.114, p.95-102, 2016.

FERGUSON, D.M.; BRUCE, H.L.; THOMPSON, J.M. et al. Factors affecting beef palatability. Farmgate to chilled carcass. Aust. J. Exp. Agric., v.41, p.879-891, 2001.

FERGUSON, D.M.; WARNER, R.D. Have we underestimated the impact of pre-slaughter stress on meat quality in ruminants? Meat Sci., v.80, p.12-19, 2008.

FISHER, A.D.; COLDITZ, I.G.; LEE, C.; FERGUSON, D.M. The influence of land transport on animal welfare in extensive farming systems. J. Vet. Behav., v.4, p.157-162, 2009.

GALLO, C. Carnes de corte oscuro en bovinos. Rev. Vetermas, v.2, p.16-21, 2003.

GALLO, C.; LIZONDO, G.; KNOWLES, T.G. Effects of journey and lairage time on steers transported to slaughter in Chile. Vet. Rec., v.152, p.361-364, 2003.

HARGREAVES, A.; BARRALES, L.; PEÑA, I. et al. Factores que influyen en el $\mathrm{pH}$ último e incidencia de corte oscuro en canales de bovino. Cienc. Invest. Agric., v.31, p.155-166, 2004.

HIRVONEN, J.; HIETAKORPI, S.; SALONIEMI, H. Acute phase response in emergency slaughtered dairy cows. Meat Sci., v.46, p.249-251, 1997. 
ISHIWATA, T.; UETAKE, K.; EGUCHI, Y.; TANAKA, T. Steer stress levels during long distance transport throughout the year in Japan. J. Anim. Sci., v.79, p.510-517, 2008.

KANEKO, J.J.; HARVEY, J.; BRUSS, M. (Eds.). Clinical biochemistry of domestic animals. San Diego: Academic Press, 2008. 928p.

KNOWLES, T.G.; WARRISS, P.D.; VOGEL, K. Stress physiology of animals during transport. In: GRANDIN, T. (Ed.). Livestock handling and transport. Wallingford: CAB International, 2014. p.399-420.

LOPEZ, O.; MARCO, I.; MONTANE, J.; LAVIN, S. Transport stress in Southern chamois (Rupicapra pyrenaica) and its modulation by acepromazine. Vet. J., v.1720, p.347-355, 2006.

McCORMACK, M.C.; KWON, E.; EBERLIN, K.R. et al. Development of reproducible histologic injury severity scores: Skeletal muscle reperfusion injury. Surgery, v.143, p.126-133, 2008.

MINKA, N.S.; AYO, J.O. Physiological responses of food animals to road transportation stress. Afr. J. Biotechnol., v.8, p.7415-7427, 2009.

MIRANDA-DE LA LAMA, G.C.; VILLARROEL, M.; MARÍA, G.A. Livestock transport from the perspective of the preslaughter logistic chain: a review. Meat Sci., v.98, p.9-20, 2014.
MORENO-SÁNCHEZ, N.; DÍAZ, C.; CARABAÑO, M.J. et al. A comprehensive characterisation of the fibre composition and properties of a limb (Flexor digitorum superficialis, membri thoraci) and a trunk (Psoas major) muscle in cattle. BMC Cell Biol., v.9, p.115, 2008.

PISTEKOVÁ, V.; OSTÁDALOVÁ I.; SEDLÁKOVÁ, J. et al. Emergency slaughter of cattle due to immobility. Acta Vet. Brno., v.73, p.533-538, 2004.

ROÇA, R.O. Modificações pós-morte da carne. 2001. Disponível em: <http://www.fca.unesp.br>. Acessado em: 10 nov. 2014.

ROMERO, M.H.; URIBE-VELÁSQUEZ, L.F.; SÁNCHEZ, J.A.; MIRANDA-DE LA LAMA, G.C. Risk factors influencing bruising and high muscle $\mathrm{pH}$ in Colombian cattle carcasses due to transport and pre-slaughter operations. Meat Sci., v.95, p.256-263, 2013.

STOCKHAM, S.L.; SCOTT, M.A. (Eds.). Fundamentos da patologia clínica veterinária. Rio de Janeiro: Guanabara Koogan, 2011. 744p.

STRYDOM, P.E.; FRYLINCK, L. Minimal electrical stimulation is effective in low stressed and well fed cattle. Meat Sci., v.96, p.790-798, 2014.

TERLOUW, E.M.C.; ARNOULD, C.; AUPERIN, B. et al. Pre-slaughter conditions, animal stress and welfare: current status and possible future research. Animal., v.2, p.15011517, 2008.

VALENTINE, B.A.; McGAVIN, M.D. (Eds.). Bases da patologia em veterinária. Rio de Janeiro: Elsevier, 2013. 1344p. 